almost all the chief food fishes, except the herring group, float at or near the surface of the water-so that they are carried hither and thither by every surge of the tide, or more steadily borne by the deeper currents to stock anew exhausted waters. The minute and imperfectly-developed embryos and the delicate young, moreover, are conveyed into regions best suited for their future growth and wellbeing. Further, we cannot but be impressed by the fitness of the arrangement which ordains that these young fishes are placed from the first amidst a rich surface-fauna of minute forms which serve them as food. These range from the microscopic Infusoria, which cause the crest of every ripple at the ship's side to sparkle with light and the tow-nets to gleam like tunnels of fire; the wonderful Plutei, or painter's easel-like larvæe of star-fishes, swarms of larval sea-acorns, Copepods, and the beautiful zoeæ of the higher crustaceans. Besides these, are the peculiar Appendiculariæ and Sagittæ, and countless myriads of larval mussels, which in summer crowd the surface of St. Andrew's Bay, and at a still later stage, as they are forsaking their pelagic existence to settle on the stones and seaweeds, form the food of the more advanced young cod, haddock, whiting, coal-fish, pollack, and others that seek shelter for a time amidst the shaggy belt of tangles encircling the rocks. The latter thus in their larval state, by nourishing in their profusion the delicate young of the food fishes, in a sense repay the wise conservancy bestowed by the Town Council of this city on the fine musselbeds of the Eden. It will, moreover, be observed that it is not only the eggs of the higher marine animals which float, but that for a long time zoologists have been familiar with the pelagic eggs and young of many invertebrate groups of importance. How else, indeed, could the ubiquitous mussels, the sedentary oysters, and the equally stationary sea-acorns and barnacles be spread throughout the ocean? Moreover, not only do these swimming larval forms nourish the very young food-fishes around them, either directly or indirectly, but as they-for instance, the young crabs, lobsters, star-fishes, and mussels-grow larger and older, a kind of rain, so to speak, of such forms takes place from the surface to the bottom, which is readily taken advantage of by the larger fishes, and thus the wonderful cycle is completed.

Finally, I need not point out to you the importance of the Marine Laboratory, to which I have already alluded, and at which the foregoing and other investigations were made during the summer. We have facilities in this and in the Practical Class, which are unusually favourable for study and research, but at the same time our responsibilities are not diminished by such advantages. We must all render an account of our stewardship. When I mention that many facts have yet to be determined in regard to our common food-fishes--their development, rate of growth, their life-histories and migrations-that we have much to find out as to the best methods of increasing such valuable fishes as the cod, the haddock, the sole, and turbot, and of maintaining that increase, it will be apparent that such problems are not only of moment to us but to the country, and that we cannot begin too soon to attempt their solution, as well as to increase our knowledge in regard to many of the lower forms of animal life.

\section{THE NEW UNIVERSITY OF STRASBURG}

THE following account of the new university buildings of Strasburg is taken, with a few abbreviations, from an article contributed to our contemporary La N'ature, by M. Charles Grad, who is himself a deputy to the Imperial Reichsrath from Alsace.

On Monday, October 27 th, 1884 , the new buildings of the University of Strasburg were opened with due formalities. These buildings form an entire quarter of the city, and constitute a magnificent series of palaces for the prosecution of science. No city in Europe, not even excepting the great capitals, can show such a rich provision for higher education, or one in which the various parts are so admirably combined. Every branch of study has its own proper and distinct location allotted to it, with laboratories, museums, library, and special appliances. It has been done on the large scale, and most successfully. The Imperial Government and the representatives of the Alsatian population arrived at an understanding, and vied in their efforts to endow the province of Alsace-Lorraine with a school of learning unrivalled in its arrangements and in its wealth of buildings. Even those who were most severely touched by the annexation to Germany, agree that in raising this splendid monument - the new University of Strasburg-the one wish has been to serve the interests of science apart from all sinister or narrow national considerations.

The former Académie of Strasburg, broken up in 1870 by the war, was replaced by the new University by virtue of a decree issued from the Chancelry of the German Empire, under date of December I Ith, I87 I-the same day on weich the additional convention of the treaty of peace was signed at Frankfort. This decree entrusted the organisation of the teaching staff to M. von Roggenbach, formerly Minister of the Grand Duchy of Baden. From

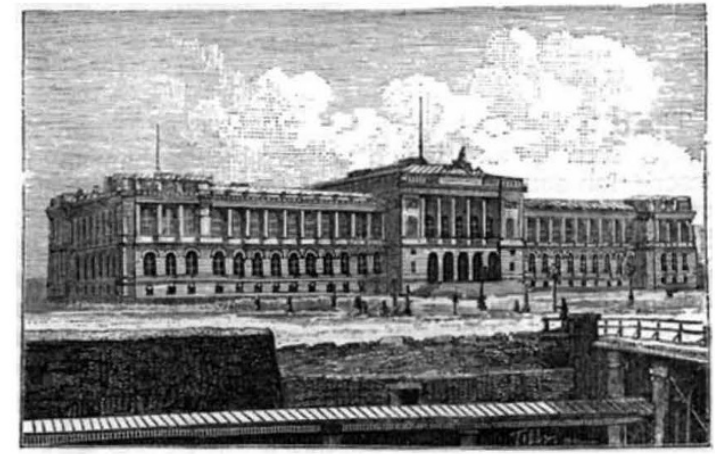

FIG. r.-University of Strasburg: The Collegiate Palace.

the summer semester of 1872 onwards a hody of fortytwo professors constituted the staff. They began their work on May ist of that year, being the three hundred and fifth anniversary of the opening of the Académie, which was founded May Ist, I 567, by the Stattmeister Johann Sturm von Sturmeck. At the present time the new University of Strasburg counts seventy-three ordinary and nineteen extraordinary professors, who during the summer semester of the year 1884 , have conducted in the five faculties no fewer than 242 courses of lectures and classes. The work is thus distributed between the five faculties :

\begin{tabular}{|c|c|c|c|c|}
\hline Faculty. & & & Professors. & $\begin{array}{l}\text { Classes } \\
\text { and Lectures. }\end{array}$ \\
\hline Theology & . & & 7 & 26 \\
\hline Law and Political $\}$ & & & 12 & 29 \\
\hline $\begin{array}{l}\text { Sclences } \\
\text { Medicine. . . }\end{array}$ & . . & & . 26 & 60 \\
\hline Philosophy . . & . . & & . 25 & 77 \\
\hline $\left.\begin{array}{r}\text { Natural Sciences } \\
\& \text { Mathematics }\end{array}\right\}$ & & & . 22 & 50 \\
\hline
\end{tabular}

Side by sicle with the laboratories and hospitals attached to each special branch of the natural and medical sciences, there exist the seminaries appropriate to the other branches of learning duly equipped for the purpose of initiating the student into the real work of his subject. A fine library of 560,000 volumes, and a reading-room furnished with $57 \mathrm{I}$ periodicals, reviews, and journals, are fitted up in the ancient episcopal residence or château, for the use of both pupils and masters. At the beginning of 
the year 1884 the University counted 858 matriculated the library, which was $1,785,000$ francs $(£ 71,400)$. There students, of whom but 266 were from Alsace-Lorraine. is also an annual endowment of $1,087,227$ francs $(f, 43,000)$ We may complete these statistical details by recalling for the maintenance of the University, and one of 150,000 how, since the annexation, the sum devoted to the outfit francs $(£ 6, \infty 00)$ for that of the library, both charged to the of the University of Strasburg has amounted to $16,000,000$ Imperial budget, to meet the current necessities, in addifrancs $(£ 640,000)$, without reckoning the value of the tion to the income derived from older special endowestablishments of the ancient Académie, or the cost of ments.

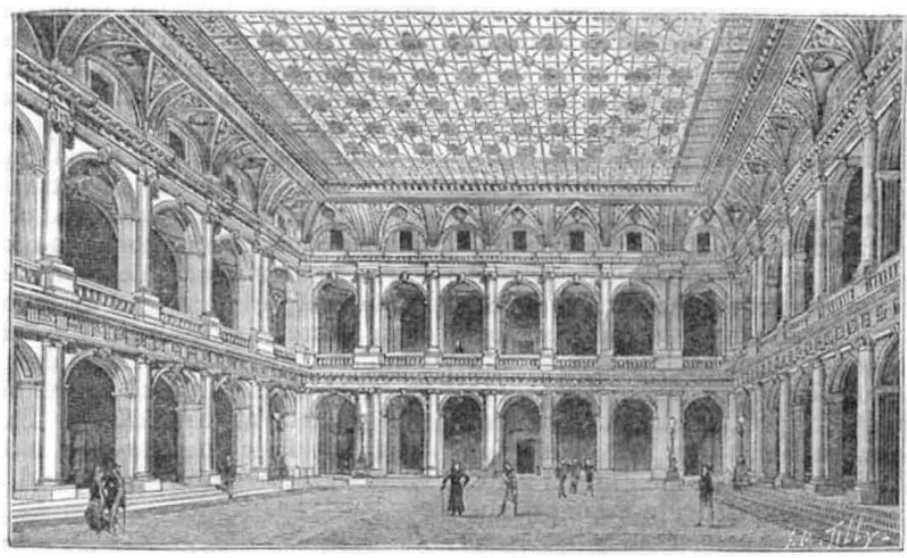

FIG. 2.-The Collegiate Palace : Salle des Pas-Perdus.

The cuts which illustrate the different establishments of der Kaiser-Wilhelms Universität. The buildings at prethe University, and which convey better than any mere sent finished are spread in two great groups around the description some faint sense of the scale on which this work has been done, and for which we have to thank the kind attention of M. Schricker, secretary of the Senate of the University, were prepared from photographs taken to accompany a memorial document published at Strasburg in I884 entitled Festschrift zur Einzeihung der Neubauten civil hospital and in the new quarter of the town now rising betwcen the Promenade des Contades and the Porte des Pêcheurs; the latter being outside the line of fortifications demolished in $187 \mathrm{I}$. It may be remembered that Strasburg now covers within its new fortifications an area thrice as great as that of the old city before its

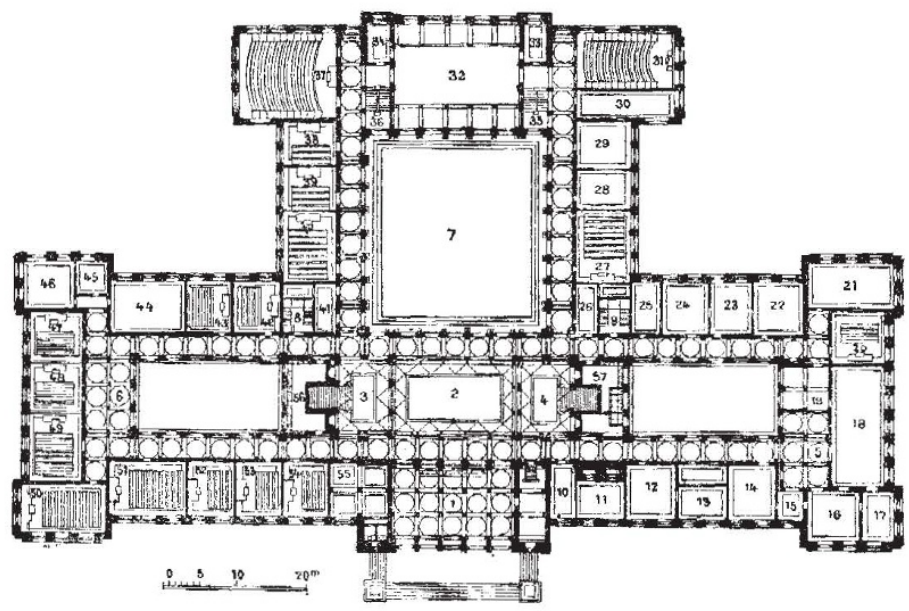

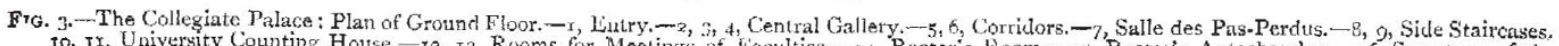
10, TY, University Counting Hoitse. $-12, T_{3}$, Roms for Meetings of liaculties. -14 , Rector's Noom. - 15, Rector's Antechamber.-16, Secretary of the

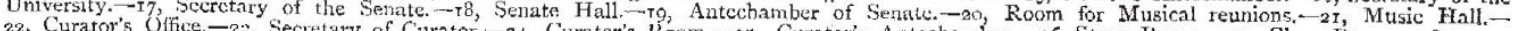

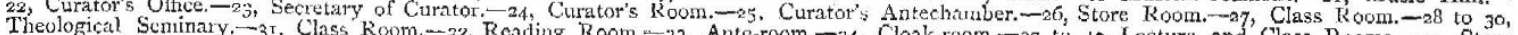
Theological Scminary. - -3T, Class Room.-32, Reading Room.-33, Ante-room.-34, Cloak-room - 37 to 40 , Lecturo and Class Rooms.-4I, Store Room.- 42,43 , Class Rooms. -41 to 46, Seminary of Mathematics. -47 to 54 , Lecture and Class Room. - 55, Professor's Parlour.- 56 , 57 , Lavatories,
8 c. -58 , Janitor.

annexation to Germany : and its population was 104,000 at the census of 1880 .

It will take you half-an-hour to walk from the medical institutes, grouped around the square of the civil hospital, across the old streets, which still preserve the primitive appearance and the rharacteristic marks of mediæval German cities, to the new collegiate palace. As you cross from the Kaiserplatz towards the Ill, there rises before you the façade of the collegiate palace, built in sandstone from the Vosges (Fig. I). This is, properly speaking, the chief building of the University, the various institutes being so many annexes. The palace is a very fine building, in the style of the Renaissance, with simple lines, standing behind a square with fountains and gardens. The plan is of an 
inverted $\mathrm{T}$ shape, giving a frontage of $4 \mathrm{IO}$ feet in length to the façade. The two lateral wings and the central member are thrown forward a little and rise slightly above the rest of the building. A fine external flight of steps leads into the interior. The basement is of red sandstone; the two stories of grey. Over the five entrance porches stand five Corinthian columns supporting a frieze, and surmounted by a group of five sculptured figures, considerably above life-size. Pallas Athene, protectress of science, stands before her throne in a calm and solemn attitude, holding up her torch in her right hand, and lowering a crown in her left. On the two sides of the throne the personifications of philosophy and natural science are each occupied in teaching a young man who reclines at their respective feet. One of these youths endeavours to raise a veil from a sphinx, under the direction of the elder muse, whilst the younger sister, with compass and crystal explains to her scholar a scientific

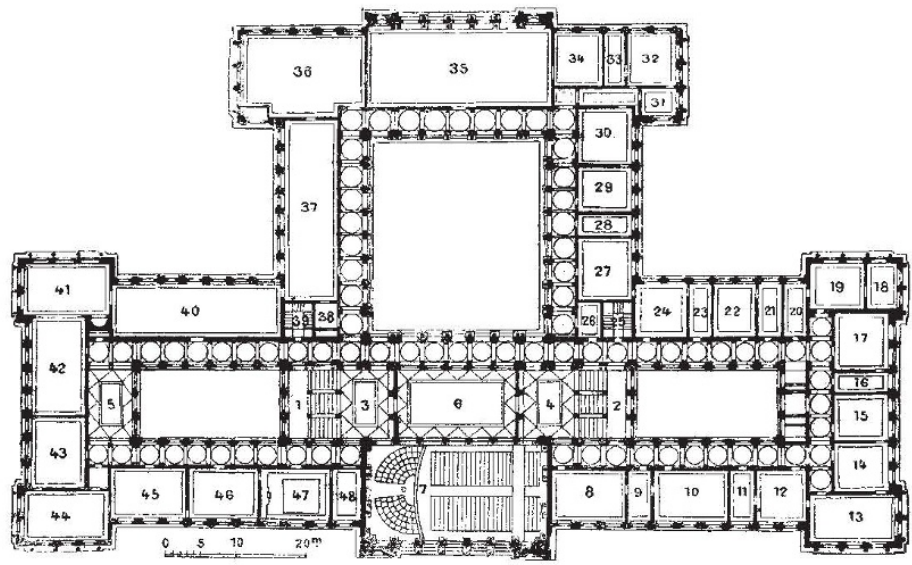

FIG. 4.-The Collegiate Palace: First Floor.-I, 2, Chief Staircases. - 3, 4, Vestibules.-5, Corridor.-6, Vestibule of the Theatre.-7, The Theatre.-8, Roman Seminary. -9 , Director's Cabinet.- ro, English Seminary.--1r to 13 , Philological Seminary.-14, I5, Institute of Archreology.-I6, I7, Seminar of German Philology. - 18 to 20 , Seminary of Geography.-21, 22, Seminary of Philosophy, $-23,24$, Seminary of Modern History,-25, Staircase. - -26 ,

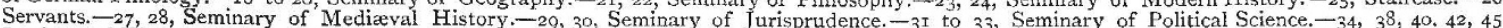
Institute of History of Ancient Art. - 39, Staircase. - 43, Hall of Egyptology. - 44 to 47 , Institute and Lecture Hall for History of Art. - 48, Library of this Institute.

problem. Under the group is the inscription in Roman letters: LITTERIS ET PATRIE. In five niches under the windows of the upper floor, and between the five columns, are five bronze busts, representing the five faculties in the persons of Saint Paul, Solon, Aristotle, Hippocrates, and Arcbimedes. Two other niches on the right and left of the five columns contain female statues personifying Strasburg and Germany. There are also thirty-six stone statues at the angles of the building. As will be seen from the plans (Figs. 3 and 4 ) the central block and each

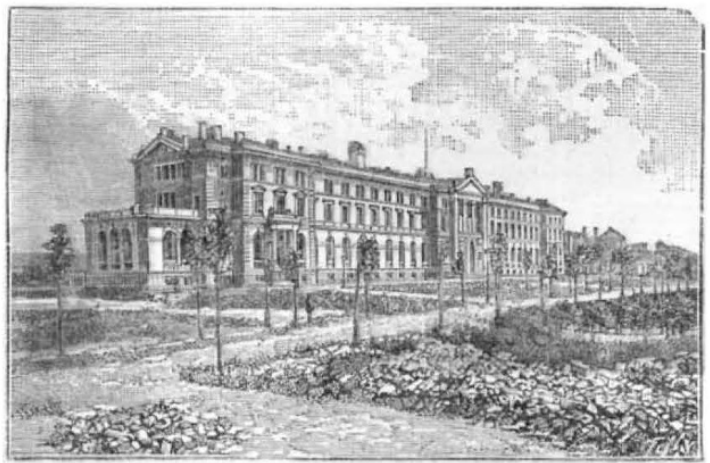

F1G. 5.-The Institute of Chemistry.

of the wings encloses an internal court. 'The central court is glazed, and constitutes an enormous hall, the Salle des Pas Perdus (Fig. 2), 92 feet long, 82 feet wide, and $52 \frac{1}{2}$ feet high. The galleries of the upper floor open upon this hall, which is lighted exclusively from the top. The inauguration ceremony was held in this hall. All official notices are posted here or in the side alleys. In allocating the various rooms of the building the architect placed on the lower storey the offices of the administrative depart- ments and the class rooms in the wings. The seminaries of the faculty of philosophy and the collections of archæology and historical art are placed, along with the aula or great theatre on the higher storey. The plans were drawn by Prof. Warth of Carlsruhe, who also directed the works of construction from 1874 to 1884 .

The official rooms of the secretary and of the rector, spacious in proportion, occupy the south wing of the ground floor, along with the scnate hall and the music hall : for musical science enters also into the curriculum

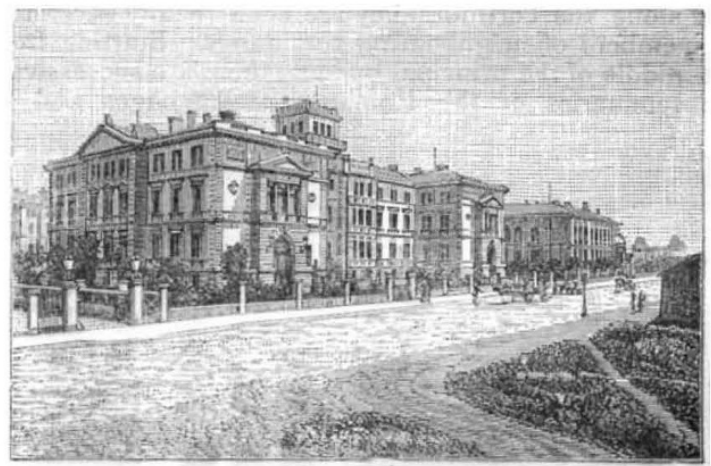

FIG, 6.-The Institute of Physics.

of the University. In the richly decorated hall for meetings of the scnate the ceiling is particularly noticeable. On the left of the entrance in the north wing of the ground floor the corridors lead to the professor's pariour and to the lecture-rooms of the various faculties. These lecturerooms contain altogether 963 seats, varying in individual rooms according to the varying requirements from 27 to 208 places. With the exception of two, the seminaries for practical studies are placed on the higher floors, so as 
to be quiet enough for their purpose. They are open either all day or during certain hours, under the superintendence or clirection of the professors, who each have their own private room beside the room allotted to students.

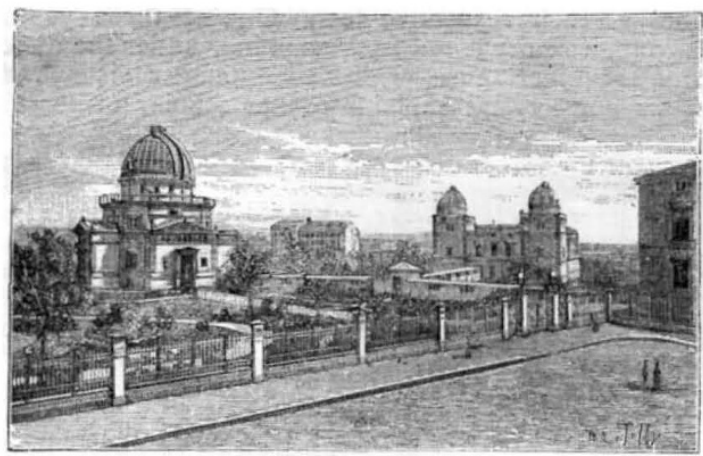

FIG. 7.-The Astronomical Observatory.

These seminaries correspond in their particular line to the laboratories of the faculty of natural science; and they provide for students' collections, appliances and special libraries for each branch of instruction. Placed side by

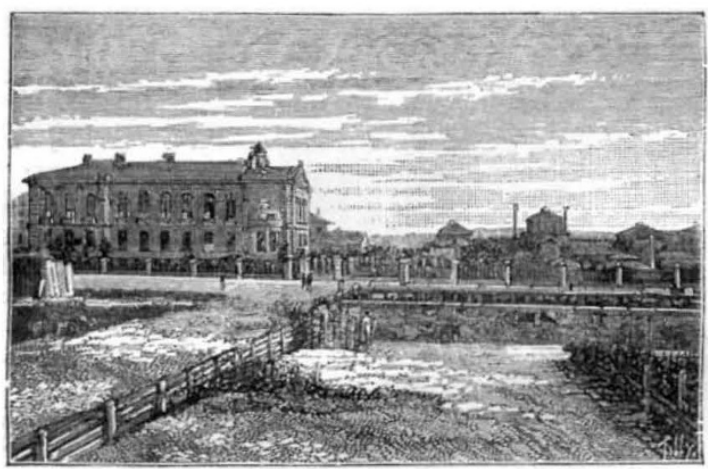

FIG. 8. - The Institute of Botany.

side along the corridors they are each readily accessible to members of neighbouring seminaries. Starting from the middle of the principal building there are successively the seminaries of the Romanesque languages and of

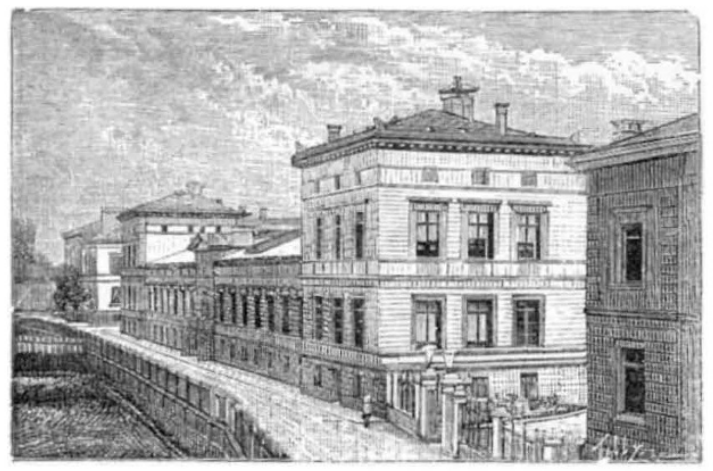

FIG. 9.-The Institute of Anatomy and Pathology.

English, the philological seminary, the institutc of archæology, the German seminary, the seminaries of historical science, of philosophy, of jurisprudence, and of political science. All the northern half of the first floor is devoted to art collections, extending from the seminary of political science to the aula or great theatre. In the middle of the western façade is the common lecture hall, flanked on the one side by the library of the institute of archaology, on the other by the rooms of the institute of historical art. A particular hall is reserved for temporary exhibitions. Then comes the hall of Egyptology and the archæological museum organised with as much taste as science by $M$. Michaelis, the professor of archæology. Egyptology and Arabic have each a special professor.

Beside the seminaries and the art collections the principal floor contains the aula or festival theatre, for the

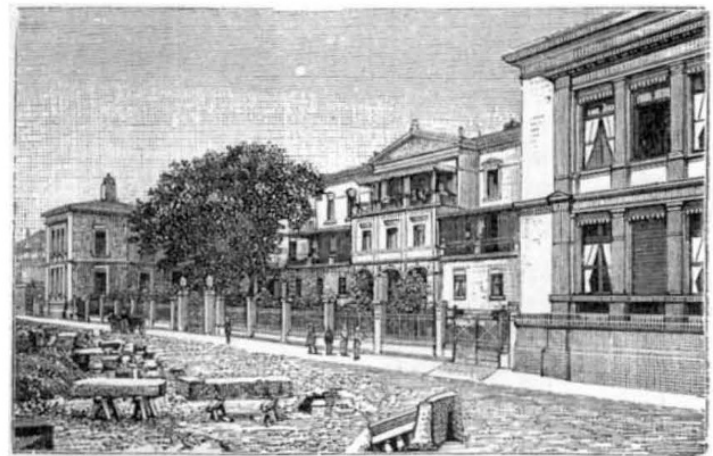

FIG. 10.-The Surgical Clinical IIospital.

University commemorations. Lit from above this hall occupies the middle of the front façade, and is approached at both ends by the grand staircases. Five open arcades separate the aula from an exterior room reserved for the public. The theatre itself is 82 feet long, $47^{\frac{1}{2}}$ wide, and 33 high. It seats 450 persons, whilst the external chamber admits of 200 to 300 standing places. The decorations are in plaster, and there is a bust of the Kaiser Wilhelm against the northern wall in whitc marble.

The heating arrangements - partly hot air, partly hot water-are in the basement, a combined system being used for the class-rooms, hot air alone for the corridors

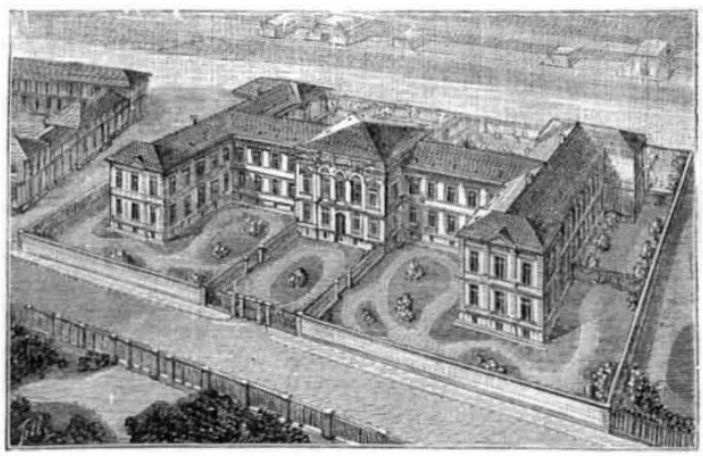

Fur. Ix.-The Clinical Hospital for Mental Disorders.

and for the great hall. The ventilation is operated by gas engines. All the windows are double-glazed to obviate too rapid cooling. No scientific appliance bas been forgotten which might secure good sanitation. The aula, the rector's apartments, the staircases, and the Salle des Pas l'erdus are richly ornamented in plaster and with painting. The lecture halls and class rooms are more simple and severe as befits their purpose, but for that very reason nothing has been omitted to give them a solid and almost monumental construction. Sandstone relieved with marble prevails in the interior; whilst the floors of the vestibules and corridors are of mosaic and terrazo. 
Each of the special institutes of chemistry, physics, botany, pharmacy, and astronomy, which are grouped behind the collegiate palace, merit a particular description, as well as the hospitals of surgery, obstetrics, and psychiatry, and the institutes of anatomy, physiological chemistry, and of physiology belonging to the faculty of medicine, which are grouped around the civil hospital. Views of these are given in Figs. 5 to I5. Each of these institutes is independent and separate from the others, provided with everything appropriate to its specific purpose. In order to enable the professors, who are the directors of the special institutes, to follow fully the work

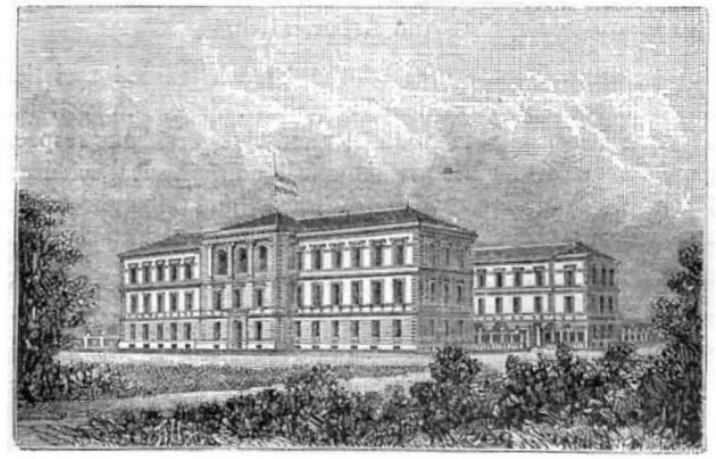

Flci. 12.-The Maternity Hospital.

of the students and the practice of the laboratory, they are provided with residential apartments in the same buildings. To the institute of astronomy is added an astronomical observatory. This is at the present time directed by Dr. Schur, in consequence of the protracted illness of Prof. Winnecke, who was assistant at the observatory of Pulkowa before coming to Strasburg. At the institute of botany, Prof. von Bary, whose work on cryptogamic flora is well known, has laid out a new botanic garden, to which a second hothouse is yet to be added. To complete the organisation of the University establishments there remain to be erected an institute of

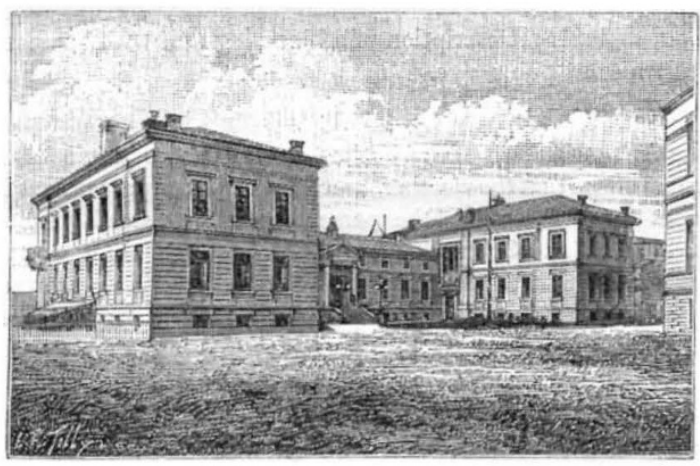

FYG. x3.-The Institute of Physiological Chemistry.

geology, an institute of zoology, and an institute of meteorology. The institute of geology, to be directed by Prof. Benecke, will receive the mineralogical and palæontological collections, and at the same time will accommodate the work of the geological survey of Alsace-Lorrainc. As to the institute of meteorology, its utility has been already admitted by the provincial government, and its establishment is only a question of time.

Toward the sum of $16,000,000$ of francs $(f, 640,000)$ expended up to this year on the new University of Strasburg the German Empire has contributed the sum of $3,800,000$ marks, or $4,750,000$ francs $(£ 190,000)$; and of this sum
$2,875,000$ francs ( $\left.f_{115}, 000\right)$ were spent on the collegiate palace. The institute of chemistry alone cost 875,000 francs $(f 35,000)$; the institute of physics, 728,750 francs ( $\left.\AA_{29}, 150\right)$; the institute of botany with its garden, 655,000 francs $(£ 26,200)$; the astronomical observatory, 642,000 francs $(t, 25,600)$; the institute of anatomy, $\mathrm{I}, 048,500$ francs $(£ 4 I, 740)$; the surgical clinical hospital, 662,500 frans ( $\approx 26,500)$; the institute of physiological chemistry, 400,000 francs $(£ 16,000)$; the institute of physiology, 337,500 francs $(£, 13,500)$. It is impossible to give here the details of each institute. Suffice it that each establishment has profited by the latest advances of science, and provides

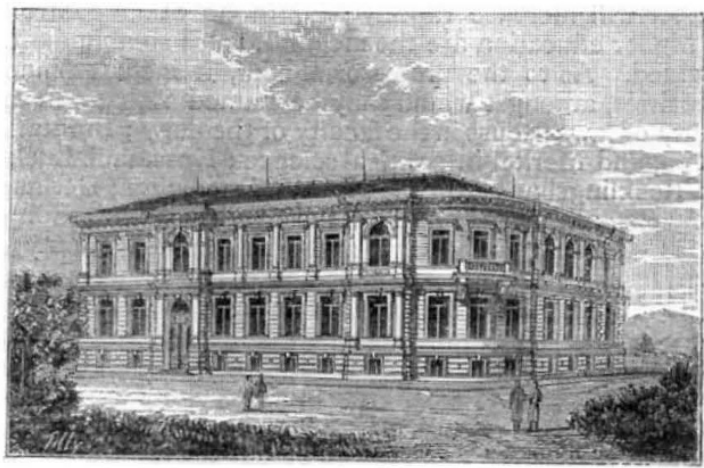

FIG. 14. - The I stitute of Pharmacy.

every means of research to students. Henceforth the institutes annexed to the University of Strasburg will serve as models for the instailation of similar buildings. They are not only most complete, but are already sought by students. Thus the institute of chemistry, under the direction of Prof. Fittig, is designed to receive Ioo students in its two divisions of organic and inorganic chemistry; and there is not a single vacant place. Further information respecting the various institutes and their organisation can be learned from the Festschrift, already alluded to as having been written by M. Schricker to commemorate the opening. As the great library of the country has been

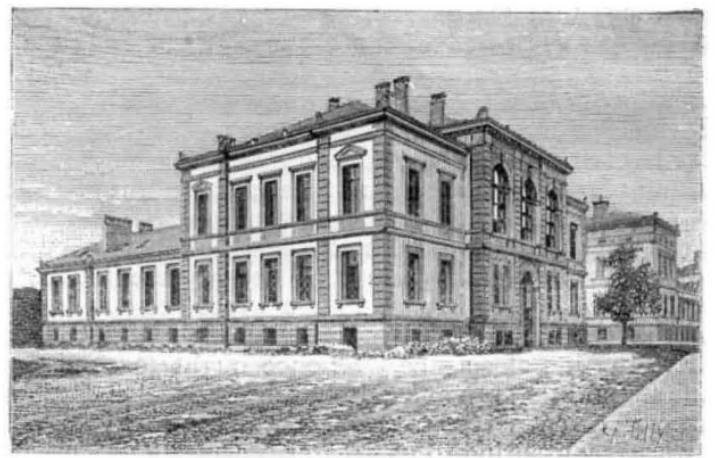

FIG. 15.- The Institute of Physiology.

but temporarily housed in the episcopal château near the Cathedral (in consequence of the fire during the bombardment of I 870 ) it is intended to remove it to the neighbourhood of the collegial palace of the University. At present, beside the special libraries of the several seminaries, there is only one reading-room (Fig. 3, No. 32) for periodicals and reviews.

Down to the present time the native Alsatians and Lorrainers have not frequented the new university as much as might have been expected in proportion to the needs of the province. Young men still turn towards France to follow their studies for the professions at Paris or at 
Nancy. Meantime the recruiting of lawyers and doctors goes on at Strasburg with foreign elements, not without some regret on the part of the native inhabitants. But little by little the force of circumstances is tending to bring the young Alsatians to constitute the University of Strasburg in spite of sentiment. Instead of 69 students, natives of Alsace-Lorraine, registered in 1872 , the University registers showed $\mathbf{2 5 2}$ in 1884 -a notable increase. As against 5,990 matriculated students at the University of Berlin, 3,399 at Leipzig, 2,276 at Munich, 1,646 at Breslau, I, 452 at Halle, 723 at Heidelberg, 625 at Freiburg, there were to be reckoned but 858 at Strasburg during the summer semester of $\mathrm{I} 884$. No doubt this number will increase rapidly; for in no other centre of the higher education are the means of work so abundantly provided. $\Lambda$ s to the professorial staff, it includes many celebrities, amongst whom may be named Labaud in the faculty of law; Reuss in the faculty of theology ; Brentano, Krapp, and Merkel in political science; Kussmaul, Lucke, and Recklingshausen in the faculty of medicine ; Gerland, Michaelis, and Studemond in the faculty of philosophy; Kundt, Benecke, von Bary, and Fittig in the faculty of natural sciences. In selecting these names we do not forget the glory of the former university of the last century, when Strasburg had amongst the number of its celebrities Profs. Blessig, Lauth, Schæepflin, Schweighauser, Oberlin, worthy predecessors of the Duvernoys, Schimpers, Gerhardts, Pasteurs, Daubrées, Sćdillots, Janets, Fustels, Coulanges, Forgets, and Kusses of our time. On August 6 th, $177 \mathrm{I}$, Goethe graduated doctor of laws of the University of Strasburg, with a thesis on the respective rights of State and Church. If to-day the new University has as an accessory function that of contributing to the Germanisation of the annexed provinces, it may at least be said that the staff of professors of the older university of last century had rallied to French politics in the most open manner. Witness the address to King Louis XV. dated October 6th, I744:- "Sire, the most faithful of the universities in your kingdom offers to your Majesty its homage and its good wishes. Penetrated with joy at the convales. cence and at the arrival of its august monarch, it to-day, Sire, finds united in you the father of the people, the protector of the muses, the liberator of Alsace, and the hero. It is to these glorifications of your rare virtues, great king, that we consecrate our work, happy if our words may correspond to the effusion of our hearts, and merit the continuation of the good graces of the most puissant and most beloved of the sovereigns of Europe."

Formerly the Académie of Strasburg took up the special task of serving as an intermediary between France and Germany for the propagation of ideas and of the scientific movement. More richly endowed, the new University, applying its greater powers to the development of the human mind, will recognise that the representatives of the people of Alsace-Lorraine have wished to promote its efforts in the largest and most generous manner in the higher interests of science. Science ought to contribute to the union of the people; it has no exclusive national character, and it serves to advance the reign of peace in the world by assuring to us greater prosperity and greater light, whilst developing in us all the love of our own country.

\section{NOTES}

THE Roya Medals of the Royal Geographical Society will this year be awarded to Mr. Joseph Thomson and Mr. H. E. O'Neill-to the former for his well-known worls in Africa, and to the latter for his thirteen journeys of exploration along the coast and in the interior of Mozambique. The Murchison Grant for 1885 will be awarded to the Pandit Kreshna for his four explorations mado while attached to the Survey of India, and especially for his extensive and important journey in the interior of Tibet. The Back Grant goes to Mr. W. O. Hodkinson for his Australian explorations, and the Cuthbert Peek Grant to Mr. J. T. Last for his surveys and ethnological researches in the Southern Masai, Nguru, and other neighbouring countries. The following will be made Honorary Corresponding Mcmbers :-Chief-Justice Daly, President of the Geographical Society of New York; M. Eliscé Rcclus, the emincnt geographer ; and Herr Moritz von Déchy, the distinguished Austrian explorer of the Sikkin Himalayas, the Caucasus, and other regions.

IT is announced that the next meeting of the American Association for the Advancement of Science will be held on August 26 and following days, at Ann Arbor, Mich.

AT the annual conference of the French learned societies, which met on the 8 th inst. in Paris, MM. Faye, Mascart, and Darbonx, were appointed president and vicc-presidents respectively of the section for the mathematical and physical sciences; and MM. de Quatrefages, Milnc-Edwards, and Maunoir to the same offices in the section for geographical and natural sciences.

M. Herve-Mangon, the new French Minister of Agriculture, is a Member of the Academy of Sciences in the Section of Rural Economy and a Professor of Agronomy to the Conservatoire des Arts et Métiers. He was for some time a Director of the establishment, but resigned in order to secure a seat in the French Lower House. He married the daughter of the late M. Dumas.

Tirt next Ordinary General Mceting of the Institution of Mcchanical Engineers will be held on Thursday, $\Lambda$ pril 30 , and Friday, May I, at 25, Great George Street, Westminster. The chair will be taken by the President, Mr. Jeremiah Head, at half-past three o'clock p.m. on Thursday, and at half-past seven o'clock p.m. on Friday. The following papers will be read and disctussed, as far as time will admit:-Description of the Maxim automatic machine-gun, by Mr. Iiram S. Maxim, of London; Abstract of results of experiments on riveted joints, with their applications to practical work, by Prof. Alexander H. W. Kennedy, of London (including the latest experiments described in Prof. Kennedy's Report, issued to the members in February); Description of the Tripier Spherical Eccentric, by M. L.ouis Poillon, of Paris; Description of a blooming mill with balanced top roll at the Ebbw Vale Works, by Mr, Calvert B. Holland, of Ebbw Vale.

The Annual Report of the French Central Meteorological Department stales that the weather forecasts last year were verified in 90 cases out of every 100 , the percentage having steadily risen from 81 in 1881 to 83 in 1882 and to 87 in 1883 . Out of 189 alarm signals sent to the ports, 128 were fully verified, $2_{4}$ were fairly correct, 37 incorrect, and only two gales were not forescen. This year the gale of January II was foretold, but that of March 22, which did such damage at Cherbourg, was not predicted. It took place in exceptional circumstances, and was of short duration.

DURING the second half of last year several communications appeared in NATURE relating to the nests from which the Chincse birkls'nest soup is made. Mr. Pryer, whose ascount of his visits to the Gomantin Caves in North Borneo, where the nests are chiefly found, initiated the discussion, has now addressed a long communication on the subject to an English journal published in Japan, the main points of which appear to be as follows :--(I) Owing to a misapprehension, $\mathrm{Mr}$. Pryer was represented as saying that the bats which inhalit the caves constructed the nests as well as the swifts. The bats have nothing to do with the nests. (2) Mr. Layard, in his letter published in NATURE (November 27, 1884), speaks of "traces of blood, from the efforts of the birds to produce the saliva." Mr. 